\title{
Assessing the Environmental Effects on Dengue Fever and Malaysian Economic Growth
}

\author{
Chuie-Hong Tan, See-Nie Lee, and Sin-Ban Ho
}

\begin{abstract}
Environmental degradation is prone to increase severe weather conditions, such as heat waves and prolonged rainfall. The purpose of the study is to examine the effect of climate factors (temperature, rainfall, rain days, humidity, sea level pressure), floods and extreme events like tropical storm, tornado, typhoon and strong wind on dengue fever cases and Malaysian economic growth in the period of year 2014-2020. A correlation test was used to find the relationship between the independent, dependent and moderating variables. The study was carried out using secondary monthly data. The results showed a significant correlation between the climate change, dengue fever cases and economic growth in Malaysia. Temperature, humidity, sea level pressure and rain fall revealed a positive correlation with dengue fever cases, while rainy days and floods showed negative correlations. Besides that, increase of temperature, humidity, sea level pressure and floods moderate with dengue fever cases significantly lead to a lower economic growth.
\end{abstract}

Index Terms-Climate change, economic growth, environmental degradation, health.

\section{INTRODUCTION}

Climatic factors (such as heat and precipitation changes) may influence the periodic and geological distribution of dengue disease in the study area. As the threat of climate change becomes more prominent in all sectors, its shadow on health care, especially the rising incidence of dengue fever, is likely to prove deadly. A recent international study showed that the prevalence of spawning dengue fever increased with a heat increase of 1 degree Celsius $\left({ }^{\circ} \mathrm{C}\right)$ [1]. We have observed temperature rises in Peninsular Malaysia and East Malaysia, which are $-0.5^{\circ} \mathrm{C}-1.5^{\circ} \mathrm{C}$ and $0.5^{\circ} \mathrm{C}-1.0^{\circ} \mathrm{C}$ respectively in the past 40 years. It is expected that in the next 100 years, the temperature in Peninsular Malaysia will rise by $1.1^{\circ} \mathrm{C}-3.6^{\circ} \mathrm{C}$, and the temperature in East Malaysia will rise by $1.0-3.5^{\circ} \mathrm{C}$. Rainfall is also expected to decrease by 8.8-18.7 percent 30 years later [2].

Mordecai et al. [3] found that rising temperatures will expand the spread of vector-borne diseases. As the earth is getting hotter, mosquitoes will thrive beyond their current habitat, thereby changing the variants of diseases such as dengue fever, malaria, West Nile virus and chikungunya fever. Various mosquitoes are acclimatized to a certain

Manuscript received May 25, 2021; revised November 29, 2021. This work was supported in part by the Malaysian Fundamental Research Grant Scheme, FRGS/1/2020/SS0/MMU/02/5.

C. H. Tan and S. N. Lee are with the Faculty of Management, Multimedia University, 63100 Cyberjaya, Malaysia (e-mail: chtan@mmu.edu.my, 1211400074@student.mmu.edu.my).

S. B. Ho is with the Faculty of Computing and Informatics, Multimedia University, 63100 Cyberjaya, Malaysia (e-mail: sbho@mmu.edu.my). temperature range just as they bring different diseases. The risk of malaria is highest at $25^{\circ} \mathrm{C}$ ( 78 degrees Fahrenheit), while zika is most likely to develop at $29^{\circ} \mathrm{C}$ ( 84 degrees Fahrenheit).

Past studies have shown that climate variables demonstrate an essential part in the Malaysia's prevalence because it directly affects the carrier's activity, bite rate, life cycle and the vector's incubation period [2], [4], [5]. The Aedes mosquito's life cycle is largely affected by climate variables, such as temperature, relative humidity and gathered rainfall [2], [6]. On a global scale, this climate change has witnessed the increasing occurrence of Aedes albopictus in the northern hemisphere [6]. It is predicted that 50-60 percent of the world's population will be inflicted to these media within 100 years as compared to only 35 percent currently due to the degree of climate change [7].

Disease-carrying mosquitoes cause approximately 1 million deaths each year. Dengue fever is rapidly becoming the most pressing health problem in Malaysia. Dengue fever cases have increased nearly 10 times in the past decade. According to media reports [8], Malaysian Ministry of Health has reported 84,688 dengue fever cases in 2020, of which at least 118 dengue patients have died. Malaysia is a country with a tropical climate, which serves a fertile breeding ground for Aedes mosquitoes. Hence, there is an increase in the number of Aedes mosquitoes.

The vector-borne diseases may burden the country's cost expenditure, and hence affect the economy growth. Research and development costs involved the intervention programs cost for dengue disease and chikungunya. Other incurred cost such as government vector control programs which include using Bti for microbial control of mosquito larvae, fogging or space spraying insecticides, as well as public education initiatives known as ComBI (Communication for Behavioral Impact) or IEC (Information Education and Communication). Vector-borne diseases have detrimental effects on economic growth and education [9]. Besides that, it also reduces country's per capita income [10], [11], decreases the volume of foreign direct investment [12] and weakens country's gross domestic productivity (GDP) [13], [14].

The purpose of this study is to assess climate change and the impact of dengue disease on economic growth in Malaysia. In the first stage, the relationship between climate variables such as rainfall, temperature and relative humidity and dengue disease cases are investigated. The second stage would be to estimate whether dengue disease affect to country's economic growth under climate change hazard.

\section{LITERATURE REVIEW}




\section{A. Dengue Disease}

In Malaysia, dengue infection is one of the most prevalent public health problems [15], [16]. The first reported dengue incident was in 1901, and it has transmitted throughout Malaysia [16].

According to the NHS 'Fit for Travel' website, it quotes:

"Dengue fever is widespread throughout the tropics and subtropics, occurring in more than 100 countries. Nearly 100 million clinical cases of dengue fever are thought to occur every year."

"Dengue is the second most commonly identified cause of fever in ill international travelers."

Dengue fever is found to be one of the main causes for the fever infection of returned travelers which may provoke new dengue outbreaks in dengue-endemic areas nowadays [17]. Dengue fever infection, especially among patients returning from Southeast Asia are caused by the pathogen from Aedes mosquitoes. The episode of dengue fever is higher than other travel-related diseases, like typhoid fever and vaccine-preventable hepatitis A.

\section{B. The Impact of Climate Change on Dengue Disease}

Climate changes has been considered in developing dengue disease and has recently captured much attention in the scientific community [18]-[25]. Climate change had disrupted natural systems, thus provoked diseases to disseminate or emerge in spaces where they had not existed. The long-term influences of climate change may alter the natural ecosystems and their effects on waterborne pathogens.

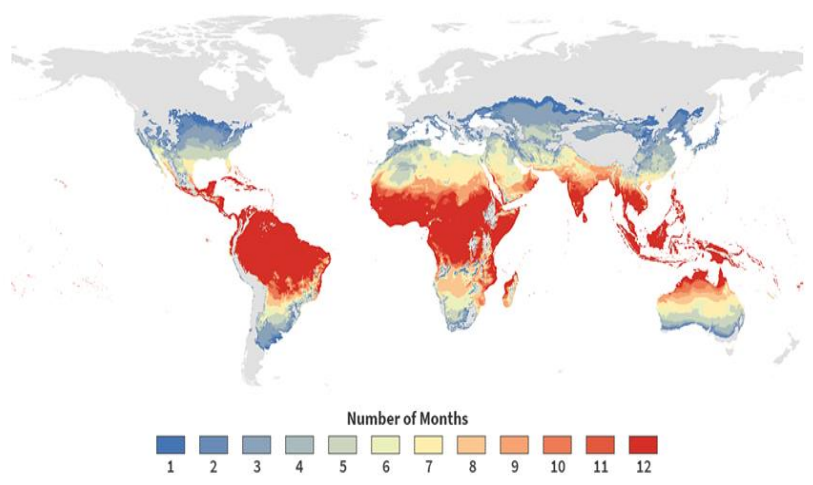

Fig. 1a. Current global circulation of the mosquito Aedes Aegypti - which may be contagious dengue fever, yellow fever, zika and chikungunya virus by duration of time in each country.

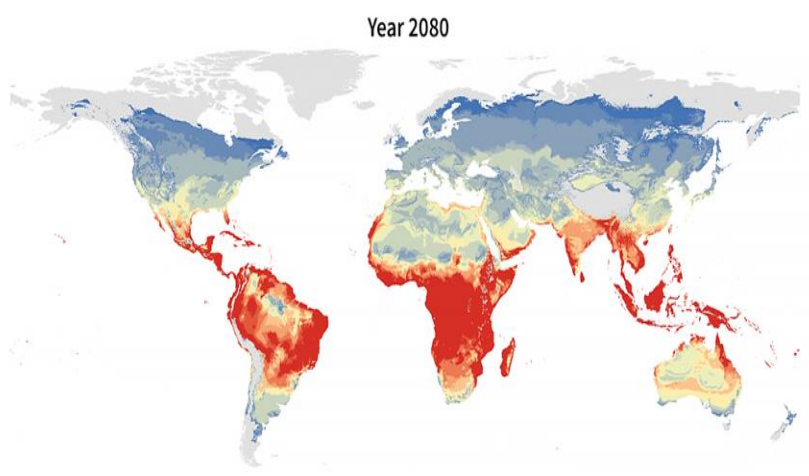

Fig. 1b. Forecasted region of the mosquito Aedes Aegypti in 2080 with consistent of worldwide greenhouse gas emissions.

Climate variables has been projected to raise the dengue models' predictive power [26]. Increased heat has been linked with dengue disease in tropical country [27]-[30]. Past research has discovered that rainfall exhibits a positive correlation with dengue cases [29], [31]. Several studies have revealed the relationship between climate variables and dengue cases in the past two decades. The use of climate variables as predictors in affecting the occurrence of dengue fever incidence has yet to be discovered and documented (Fig. $1 \mathrm{a}$ and Fig. 1b).

\section{Economic Burden of a Dengue Disease}

Dengue disease embodies a significant economic burden to publics and health services in many hot and humid countries. In the past 30 years, studies show that there is a four-fold increase in the number of dengue cases [32]-[35].

It is reported that yearly economic burden of dengue disease of US\$41.9 $( \pm 4.28 \mathrm{SE})$ million was estimated in Malaysia during period 2001-2005. The dengue costs included dengue illness expenses, vector control, as well as dengue-related government research and development, which contributed yearly costs of US\$134 million in Malaysia [36].

The cost in dengue illness is significant and contributed to 3 percent -7 percent of the government's health care expenditure. In Malaysia, the dengue illness costs are 11 times more than the expenditure on Aedes vector control [36]. It was found that an annual economic burden of dengue illness of US\$56 million (Malaysian Ringgit 196 million) which is equivalent to US\$2.03 (Malaysian Ringgit 7.14 million) per capital based on an adjusted estimate of total dengue cases [34].

The high dengue fever cases may increase government burden spending on healthcare facilities (healthcare professional, medicine, health worker, vaccine), healthcare facilities maintenance, vaccine development as well as dengue prevention, control and surveillance. Nevertheless, the cost of research and development for introducing healthcare policy and the operation of existing and new technologies will increase economic burden in Malaysia, and thus affect economic growth.

\section{HYPOTHESIS DEVELOPMENT}

Climate changes will lead to common infectious endemic diseases such as dengue, cholera, malaria, Japanese encephalitis, leptospirosis, meningococcal meningitis and rickettsia infections.

Infectious diseases may cause economic growth to decline. The literature shows that there is a close connection between health and macroeconomics, because the health of the population can improve the economic situation by increasing labor productivity, education and investment levels, and demographic changes, thereby improving the country's economic outcomes. Diseases transmitted by climate change or foreign tourists may threaten the health of the domestic population, thereby reducing productivity and affecting economic growth.

Furthermore, the World Travel and Tourism Council estimates that after the SARS epidemic in China, Hong Kong, Vietnam, and Singapore, which was most severely affected, 
about 3 million people were unemployed in the tourism industry, causing losses of more than US\$20 billion [37]. This may lead to the decrease on country's economic growth.

Nevertheless, the vector-borne diseases may bring burden of country's cost expenditure, such as healthcare facilities, facilities maintenance costs, cost of research and development for introducing health policy priorities, the cost of intervention program and the cost of government vector control program to mitigate chikungunya and dengue disease.

The following stated hypotheses tested for a clear understanding of the impact of dengue disease risk on Malaysian economic growth under climate change hazard.

H1: Climate change lead to dengue disease risk in Malaysia

$\mathrm{H} 2$ : Climate change moderate the relationship between dengue disease risk and economic growth (GDP). The stronger (less) climate change leads to lower (higher) economy growth.

\section{Methodology AND DATA}

Volatility of surface air temperature, sea surface temperature, sea level, changes in Arctic sea ice and precipitation, and the occurrence of severe weather are usual parameters to record the climate change [38], [39]. However, changes in Arctic sea ice have become irrelevant in tropical countries such as Malaysia.

In this study, heat temperature and sea level data at designated locations are gathered. A weather station captures the climate change trend in the main areas of Peninsular Malaysia and Borneo, Malaysia. In every major region of Malaysia, at least one station with comprehensive climate data is selected. Part of the weather stations are located in the cities Kota Kinabalu and Kuching to capture climate change in Sabah and Sarawak respectively. In Peninsular Malaysia, the selected sites are Malacca (west coast), Kuantan (east coast) and Subang/Kuala Lumpur. GRETL software is employed to analyse the effect of climate change on dengue fever cases by using panel data. Furthermore, E-views software is used to run the time series data investigating the effect of dengue fever on economic growth under climate change condition.

\section{A. Mean Daily Temperature}

Fig. 2a shows that from January 2014 to September 2020, in Kota Kinabalu, the annual moving average of mean daily temperature was on an upward trend, shifting between $25.7^{\circ} \mathrm{C}$ and $29.6^{\circ} \mathrm{C}$. Similar trends were detected in other stations. The temperature change ranges from $25.4^{\circ} \mathrm{C}$ to $28.9^{\circ} \mathrm{C}$ in Kuching, from $26.1^{\circ} \mathrm{C}$ to $29.6^{\circ} \mathrm{C}$ in Malacca, from $24.9^{\circ} \mathrm{C}$ to $28.6^{\circ} \mathrm{C}$ in Kuantan and between $26.5^{\circ} \mathrm{C}$ to $29.7^{\circ} \mathrm{C}$ in Kuala Lumpur/Subang. The degree of increase in the annual moving average of mean daily temperature was lowest for Kuantan, then followed by Kuching, Kota Kinabalu, Malacca and Kuala Lumpur/Subang in increasing order, as shown by the linear trendline gradient (Fig. 2a). The reported approximate rate of mean temperature increase was about $0.25^{\circ} \mathrm{C}, 0.20^{\circ} \mathrm{C}$ and $0.14^{\circ} \mathrm{C}$ per decade in Peninsular Malaysia, Sabah and Sarawak respectively [40]. El Nino phenomena has caused the temperature spikes in the period of 2015-2016 (see Fig. 2a, 2b, 2c and 2d). In the past 45 years, the frequency of $\mathrm{El}$ Niño has become more pronounced [41].

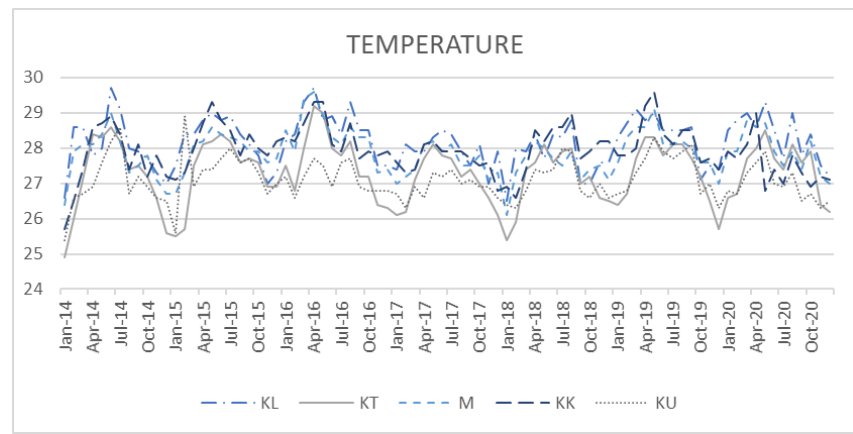

Fig. 2a. Monthly moving average of mean daily temperature in Kuala Lumpur/ Subang (KL), Kuantan (KT), Malacca (M), Kota Kinabalu (KK) and Kuching (KU).

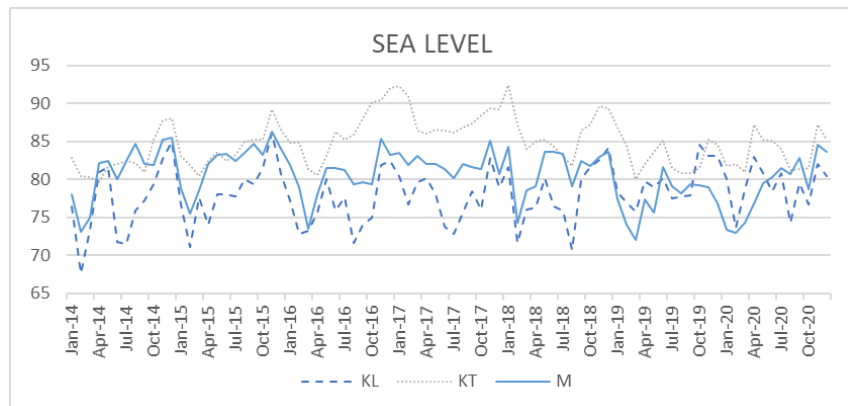

Fig. 2b. Monthly moving average of mean daily sea level in Kuala Lumpur/ Subang (KL), Kuantan (KT), Malacca (M), Kota Kinabalu (KK) and Kuching (KU).

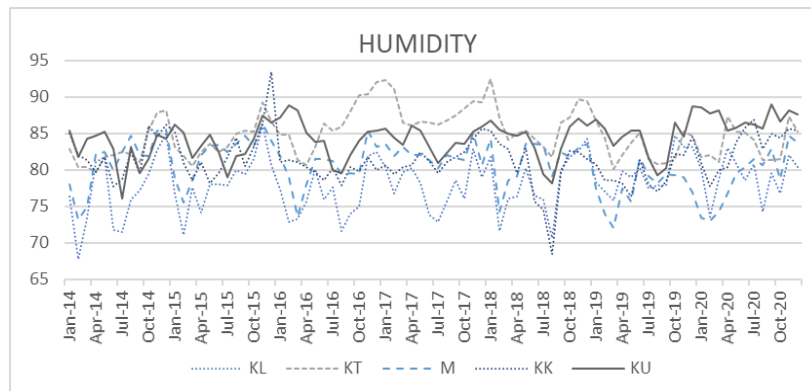

Fig. 2c. Monthly moving average of mean daily humidity in Kuala Lumpur/ Subang (KL), Kuantan (KT), Malacca (M), Kota Kinabalu (KK) and Kuching (KU).

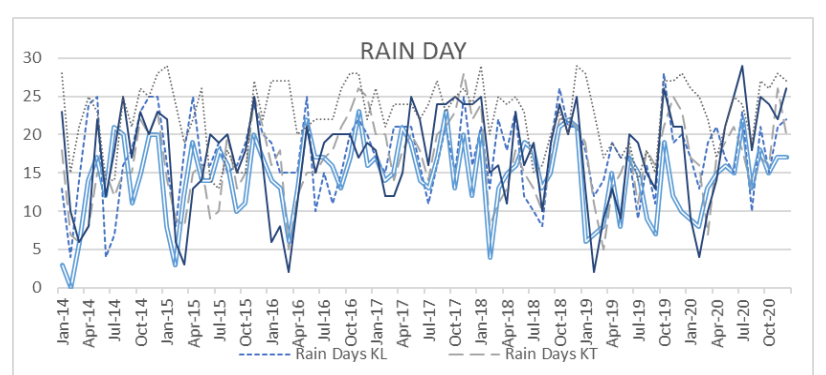

Fig. 2d. Monthly moving average of mean daily rain day in Kuala Lumpur/ Subang (KL), Kuantan (KT), Malacca (M), Kota Kinabalu (KK) and Kuching (KU).

Source: Tutiempo Network [42]

\section{B. Extreme Weather}

Severe climate incidence in Malaysia are considered by high temperature, high rainfall, drought, strong winds and thunderstorm. Acute weather incidences have numerously recorded recently. During the 2006/2007 monsoon, the worst 
flooding occurred in the southern part of Peninsular Malaysia. Since the 1980s, the days of extreme rainfall events have been increasing. According to Sammathuria and Ling [41], the number of yearly thunderstorm days and strong wind days have increasingly occurred. Under the influence of El-Nino, the temperature surge in Fig. 2a, 2b, 2c and $2 d$ clearly demonstrates the increase in high-temperature years [43]. Khor [44] discovered that the happening of drought and heavy rainfall is an emerging annual climate trend in Malaysia. Table I and Table II depict the growing histories of flood and severe weather incidence in Malaysia.

TABLE I: THE INCIDENCE OF MAJOR FLOODS IN MALAYSIA

\begin{tabular}{|c|c|c|}
\hline Date & Area & Detail \\
\hline Jan 1971 & $\begin{array}{l}\text { Kuala } \\
\text { Lumpur, } \\
\text { Malaysia }\end{array}$ & $\begin{array}{l}\text { Since year 1926, heavy monsoon rains } \\
\text { and flood resulted in } 32 \text { deaths and affected } \\
180,000 \text { victims. }\end{array}$ \\
\hline $\begin{array}{l}\text { Dec } 2006 \\
\text { - Jan } 2007\end{array}$ & $\begin{array}{l}\text { Southeast } \\
\text { Asian }\end{array}$ & $\begin{array}{l}\text { Flash flood hit Johor severely and to a } \\
\text { lower degree, Negeri Sembilan, Malacca } \\
\text { and Pahang due to Typhoon Utor and heavy } \\
\text { rainfall, }\end{array}$ \\
\hline Jun 2007 & $\begin{array}{l}\text { Kuala } \\
\text { Lumpur, } \\
\text { Malaysia }\end{array}$ & $\begin{array}{l}\text { Since } 10 \text { June } 2003 \text {, the flash flood hit } \\
\text { Kuala Lumpur. }\end{array}$ \\
\hline Dec 2007 & $\begin{array}{l}\text { Certain } \\
\text { regions of } \\
\text { East Coast of } \\
\text { Peninsula } \\
\end{array}$ & $\begin{array}{l}\text { The flash flood hit the states of } \\
\text { Terengganu, Johor, Pahang and Kelantan in } \\
\text { Malaysia. }\end{array}$ \\
\hline $\begin{array}{l}\text { Oct - Nov } \\
2010\end{array}$ & $\begin{array}{l}\text { North } \\
\text { Malaysia and } \\
\text { Thailand }\end{array}$ & $\begin{array}{l}\text { Due to the La Nina monsoon rainfall a } \\
\text { late monsoon occurs from Bengal Bay. The } \\
\text { flood hit several areas in Malaysia and } \\
\text { Thailand. The flood killed } 232 \text { people in } \\
\text { Thailand and } 4 \text { deaths in Malaysia. }\end{array}$ \\
\hline $\begin{array}{l}\text { Jan - Feb } \\
2014\end{array}$ & $\begin{array}{l}\text { Sabah, } \\
\text { Malaysia }\end{array}$ & $\begin{array}{l}\text { Flash flood affected various areas of } \\
\text { Sabah including Penampang, Tuaran and } \\
\text { Menggatal due to torrential rainfall. }\end{array}$ \\
\hline $\begin{array}{ll}\text { Dec } 2014 \\
\text { - Jan } 2015\end{array}$ & $\begin{array}{l}\text { Southeast } \\
\text { Asia and } \\
\text { South Asia }\end{array}$ & $\begin{array}{l}\text { Floods hit Sri Lanka, West Malaysia, } \\
\text { Indonesia, and South Thailand due to the } \\
\text { northeast monsoon, involving more than } \\
417,000 \text { victims. }\end{array}$ \\
\hline $\begin{array}{l}\text { Jan - Feb } \\
2015\end{array}$ & East Malaysia & $\begin{array}{l}\text { Due to intensified northeast monsoon, } \\
\text { many areas of Sabah and Sarawak were hit } \\
\text { by flooding, affecting } 13,878 \text { citizens. }\end{array}$ \\
\hline $\begin{array}{l}\text { Feb - Mar } \\
2016\end{array}$ & Malaysia & $\begin{array}{l}\text { Due to heavy rainfall, floods occurred in } \\
\text { Johor, Sarawak, Malacca and regions of } \\
\text { Negeri Sembilan. }\end{array}$ \\
\hline $\begin{array}{l}\text { Dec } 2016 \\
- \text { early of } \\
2017\end{array}$ & $\begin{array}{l}\text { Southern } \\
\text { Thailand }\end{array}$ & $\begin{array}{l}\text { The annual monsoon season at Southern } \\
\text { Thailand brought flash flood in Kelantan } \\
\text { and Terengganu. It costed to an } \\
\text { approximated loss of USD } 4 \text { billion, } \\
\text { particularly cost on infrastructure, tourism } \\
\text { and agriculture. }\end{array}$ \\
\hline Nov 2017 & $\begin{array}{l}\text { Penang, } \\
\text { Malaysia }\end{array}$ & $\begin{array}{l}\text { The worst in the state of Penang, } \\
\text { Malaysia was resulted from tropical cyclone } \\
\text { [45]. Around } 3000 \text { people was forced to } \\
\text { evacuate due to flash flood after hours of } \\
\text { torrential rain. }\end{array}$ \\
\hline Jan 2018 & Malaysia & $\begin{array}{l}\text { Due to the annual northeast monsoon } \\
\text { which led to heavy rain, Terengganu, Johor, } \\
\text { Pahang and Sabah were badly affected by } \\
\text { floods. The flood killed } 2 \text { people in Pahang } \\
\text { and affected around } 12,000 \text { victims [46]. }\end{array}$ \\
\hline Oct 2019 & Malaysia & $\begin{array}{l}\text { Storm and flood hit Selangor, Perak, } \\
\text { Johor, Penang, Kedah, Perlis. It has affected } \\
\text { 2,371 people from } 657 \text { families. }\end{array}$ \\
\hline Nov 2019 & Malaysia & $\begin{array}{l}\text { The flash flood hit Johor, Kelantan, } \\
\text { Pahang and Terengganu. The flood killed } 2 \\
\text { dead and bringing } 15,000 \text { people displaced } \\
\text { as floods worsen in Kelantan and } \\
\text { Terengganu. }\end{array}$ \\
\hline Nov 2020 & Malaysia & Pahang and Johor are badly affected by \\
\hline
\end{tabular}

\begin{tabular}{|l|l|l|}
\hline - Early of & & $\begin{array}{l}\text { the flood this round. Terengganu, Kelantan, } \\
\text { Selangor and Perak are also involved. In } \\
\text { Sabah, flood happened in Beaufort. The } \\
\text { flood has affected } 8,000 \text { people to evacuate } \\
\text { their homes. Continuous heavy pours for } \\
\text { several days due to the Northeast Monsoon } \\
\text { Winds hit across Peninsular Malaysia }\end{array}$ \\
\hline
\end{tabular}

TABLE II: OTHER SEVERE CLIMATE INCIDENCE IN MALAYSIA

\begin{tabular}{|l|l|l|}
\hline \multicolumn{1}{|c|}{ Date } & Area & \multicolumn{1}{c|}{ Detail } \\
2001 & $\begin{array}{l}\text { Eastern } \\
\text { Peninsular } \\
\text { Malaysia }\end{array}$ & $\begin{array}{l}\text { Tropical Storm Vamei from South } \\
\text { China Sea brought landslides and flash } \\
\text { flood to the eastern Peninsular Malaysia. }\end{array}$ \\
\hline $\begin{array}{l}\text { October } \\
\text { November }\end{array}$ & $\begin{array}{l}\text { Peninsular } \\
\text { Malaysia }\end{array}$ & $\begin{array}{l}\text { The EF3 tornado incident that } \\
\text { happened for 10-15 minutes with wind } \\
\text { velocity to 240 km/h hit the states of } \\
\text { Kedah and Selangor. In 2010, the frequent } \\
\text { tornado incidents in Perlis, Penang and } \\
\text { Selangor were due to changes in monsoon } \\
\text { season. }\end{array}$ \\
\hline October 2017 & $\begin{array}{l}\text { Typhoon Paolo which was formed by a } \\
\text { Sabah, } \\
\text { Malaysia } \\
\text { strong cyclone landed on Sabah, causing } \\
\text { the state. Damages were reported. }\end{array}$ \\
\hline $\begin{array}{l}\text { December } \\
2017\end{array}$ & $\begin{array}{l}\text { Malaysian } \\
\text { Borneo }\end{array}$ & $\begin{array}{l}\text { Strong winds crossed the west coast of } \\
\text { Sabah, Labuan and Sarawak at a velocity } \\
\text { of 40-50 km/h due to storm Kai Tak } \\
\text { originated from western Pacific Ocean. }\end{array}$ \\
\hline $\begin{array}{l}\text { February } \\
2018\end{array}$ & Penang, & $\begin{array}{l}\text { In Penang, a small tornado was reported } \\
\text { and has damaged the building roof. }\end{array}$ \\
\hline
\end{tabular}

\section{Rainfall and Rain Day}

Periodic rainfall data depicts high variability which shared similar results from other research findings [41], [43], [47]. Fig. $3 \mathrm{~d}$ shows the monthly rainfall of Kota Kinabalu reached a peak of $635.24 \mathrm{~mm}$ in December 2010. In Kuantan, the monthly rainfall peaked at the end of year 2014, $1818.9 \mathrm{~mm}$ (Fig. 3b). The observed data in Kuching (Fig. 3e) and Subang (Figure 3a) show that the rainfall peaked in February 2016 and October 2019, respectively. In other regions, August 2017 and June 2019 had the highest rainfall, but the yearly rainfall peaks were significant, especially in Malacca (Fig. 3c) and Kota Kinabalu (Fig. 3d). The figure also shows changes in monthly rainfall. Fig. 3 shows the average monthly rainfall in Malaysia. The annual upsurge in rainfall is due to the northeast monsoon, which is characterized by strong north easterly and easterly winds from the South China Sea during November until February, thus cascading the wet season to the area [48]. Rahman et al. [49] found that higher annual precipitation by the La Nina incidents whereby the temperatures of sea surface in the east central Equatorial Pacific fall below average. Fig. 3a-e depicts that higher average rainfall is connected with increasing number of rainy days, on the whole.

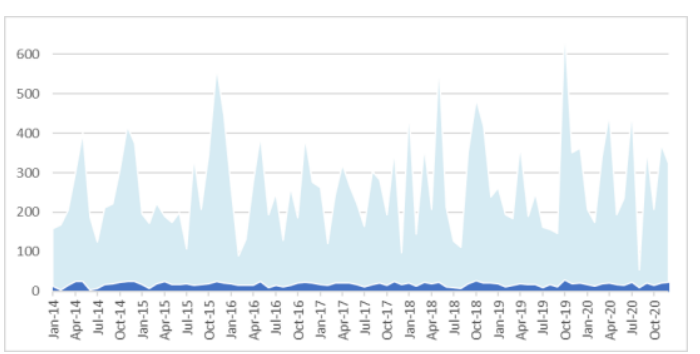

Fig. 3a. Average monthly precipitation and rainy days in Kuala Lumpur/Subang (KL). 


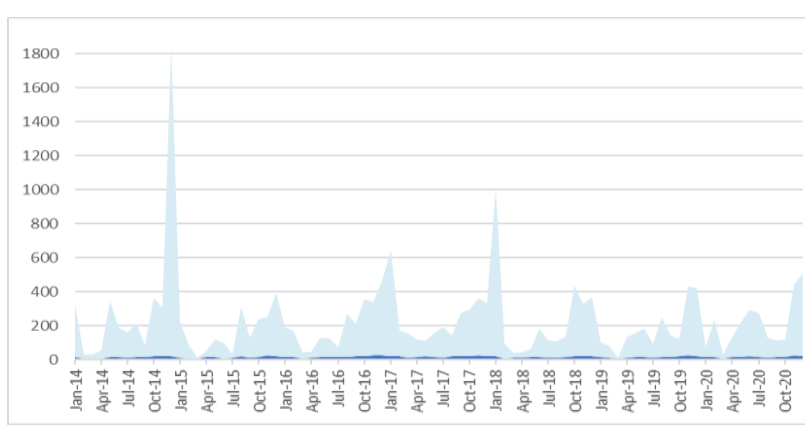

Fig. 3b. Average monthly precipitation and rainy days in Kuantan (KT).

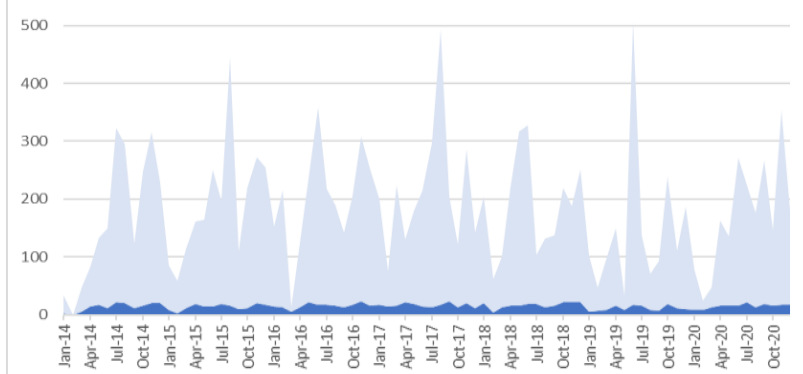

Fig. 3c. Average monthly precipitation and rainy days in Malacca (M).

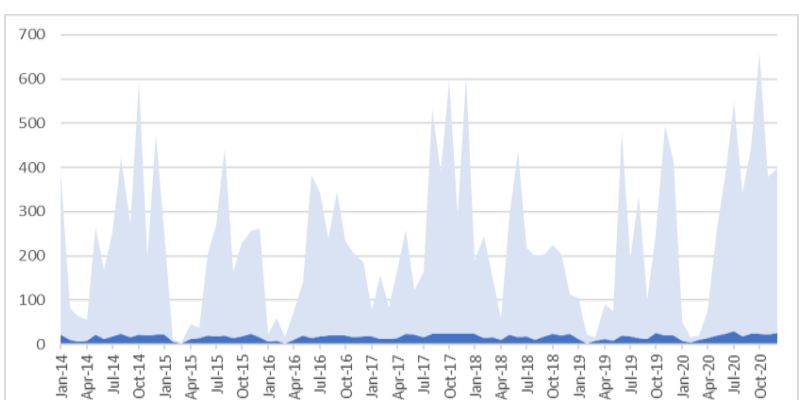

Fig. 3d. Average monthly precipitation and rainy days in Kota Kinabalu (KK).

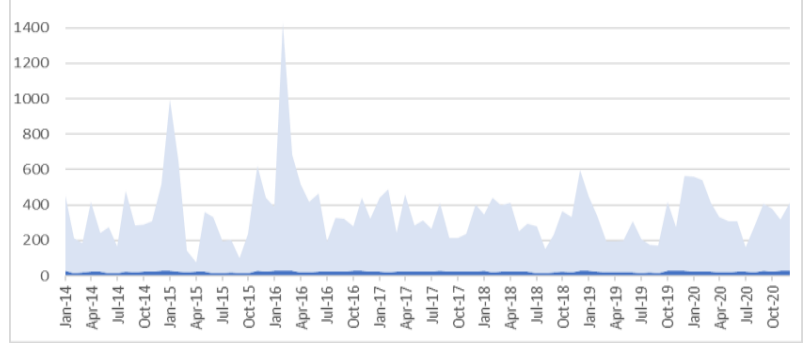

Fig. 3e. Average monthly precipitation and rainy days in Kuching (KU).

The collected data was analyzed using simple regression analysis. This study utilizes seven years of monthly data starting from January 2014 to December 2020. For the analysis testing the first hypothesis, the variables included in this study are dengue illness cases in Malaysia as the dependent variable, and climate variables, which are temperature, rainfall and humidity in Malaysia, as independent variables. In the second hypothesis testing, variable country's gross domestic productivity (GDP) is used as the dependent variable while variable dengue disease is the moderating variable.

Each dengue fever case reported in Malaysia between 2014 and 2020 was collected from National Crisis Preparedness and Response Centre (CPRC), Ministry of Health Malaysia (MOH). In addition, past studies linked to future climate change predictions, especially average temperature, average rainfall, and average sea level, was analyzed to test the consistency of such predictions. Climate change data such as temperature, rainfall and humidity data were collected from the Tutiempo Network. The instruments used to measure the independent variables were a thermometer for temperature, tipping for rainfall index and hygrometer for humidity. The yearly gross domestic productivity (GDP) collected data from the World Bank was then converted into average monthly data.

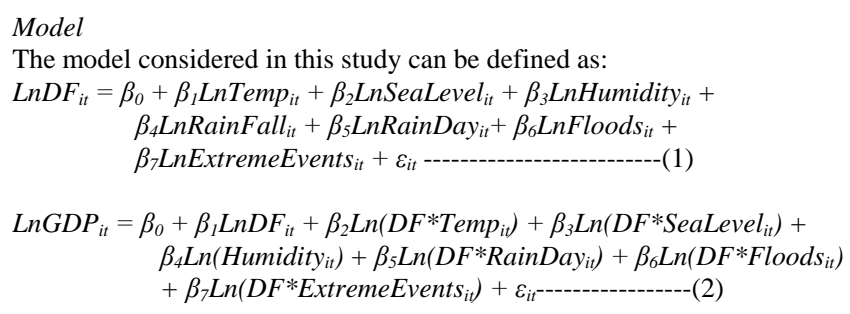

The dependent variable GDP is the gross domestic productivity of Malaysia for the period 2014-2020. The explanatory variables are defined as follows: DF is the monthly dengue fever cases in Malaysia; SeaLevel is atmospheric pressure of sea level in $\mathrm{hPa}$; Humidity is total average relative humidity in percentage; RainFall is total rain fall in mm; RainDay is total rain day in monthly; Temp is the average monthly temperature in ${ }^{\circ} \mathrm{C}$. All the climate data are collected in cities of Malaysia such as Kuala Lumpur/Subang, Malacca, Kuantan, Kuching and Kota Kinabalu. Floods and extreme events are the total day of floods and extreme events in average monthly.

\section{EMPIRICAL RESULTS}

The first hypothesis proposes that most of the estimates in Table III show a significant positive coefficient for the dengue fever. This implies that climate change in temperature, sea level pressure, humidity and rain fall lead to an increase in dengue fever cases in Malaysia. The estimates of the coefficient of average monthly temperature change on dengue disease are positively significant $2.642,3.339$ and 2.349 with a 1 percent and 5 percent level of significance, under Ordinary Least Square (OLS), Fixed-Effects (FE) and First Difference Generalised Method of Moments (FD-GMM) systems respectively. This implies that a 1 percent of climate change of temperature leads to an increase of 2.6 to 3.3 dengue fever cases in Malaysia. The estimates of the coefficient of average monthly sea level change on dengue disease are positively significant 180.061, 197.798 and 83.632 with a 1 percent level of significance, under the three selected models respectively. Nevertheless, the result reveals a positively significant of humidity 0.852 and 1.236 on dengue fever cases in Malaysia, at 10 percent (OLS) and 1 percent (FD-GMM) significant level respectively. Rain fall also reveals a positively significant on dengue fever cases. However, the estimate of the coefficient of rain days on dengue disease is negatively significant $-0.012,0.009$ and -0.010 with a 10 percent and 5 percent level of significance, by OLS, FE and FD-GMM models respectively. Besides that, the result also shows that the increase of floods will lead to lower dengue fever cases in Malaysia. 
TABLE III: EFFECT OF Climate Change on DENGUE FEVER CASES

\begin{tabular}{|c|c|c|c|}
\hline Variables & OLS & FE & FD-GMM \\
\hline \multirow[b]{2}{*}{ LOG(Temperature) } & $2.642^{* *}$ & $3.339^{* * * *}$ & $2.349^{* * *}$ \\
\hline & 0.854 & 0.466 & 1.072 \\
\hline \multirow{2}{*}{ LOG(Sea Level Pressure $)$} & $183.061^{* * * *}$ & $197.798^{* * * *}$ & $83.632^{* * * *}$ \\
\hline & 16.390 & 10.786 & 26.747 \\
\hline LOG(Humidity) & $\begin{array}{r}0.852 * \\
0.333\end{array}$ & -0.009 & $1.236 * * *$ \\
\hline \multirow[b]{2}{*}{ Rain Day } & $\begin{array}{r}0.333 \\
-0.012^{* *}\end{array}$ & $\begin{array}{r}0.993 \\
-0.009 *\end{array}$ & $\begin{aligned} 0.663 \\
-0.010^{* * *}\end{aligned}$ \\
\hline & 0.003 & 0.005 & 0.005 \\
\hline \multirow{2}{*}{$L O G($ Rain Fall $)$} & $0.051^{* * *}$ & $0.0776^{* * * * *}$ & 0.057 *** \\
\hline & 0.011 & 0.020 & 0.029 \\
\hline \multirow[t]{2}{*}{ Floods } & $-0.343 * * *$ & $-0.341 * * *$ & $-0.184^{* * * *}$ \\
\hline & 0.008 & 0.011 & 0.070 \\
\hline Extreme Events & $\begin{array}{r}-0.00206561 \\
0.0386559\end{array}$ & $\begin{array}{l}0.0184973 \\
0.0257696\end{array}$ & $\begin{array}{l}0.0565885 \\
0.0443898\end{array}$ \\
\hline Constant & $\begin{array}{r}-1269.98 * * * \\
117.127\end{array}$ & $\begin{array}{r}-1370.67 * * * \\
79.5377\end{array}$ & $\begin{array}{r}-587.523 * * * \\
187.270\end{array}$ \\
\hline \multicolumn{4}{|l|}{ Diagnostic tests } \\
\hline Wald test [p-values] & $\begin{array}{r}8.933 \text { **** } \\
0.000\end{array}$ & $\begin{array}{r}1.882 * * * \\
0.000\end{array}$ & $\begin{array}{r}264.945^{* * *} \\
{[0.0000]}\end{array}$ \\
\hline AR(2) test [p-values] & & & $\begin{array}{r}0.7847 \\
{[0.4326]}\end{array}$ \\
\hline Hansen J-test [p-values] & & & $\begin{array}{r}248.007 \text { **** } \\
{[0.0000]}\end{array}$ \\
\hline Observations & 250 & 250 & 250 \\
\hline
\end{tabular}

OLS = Pooled Ordinary Least Squares, FE = Fixed Effect (within estimator), and FD-GMM = First Difference Generalised Method of Moments

The second hypothesis proposes that an increase of dengue fever cases leads to lower Malaysian economic growth (GDP). In Table IV, the regression coefficient is 25.924 significant at 5 percent level. The result reveals that most of the estimates are consistent with the expected sign with a significant negative coefficient for the GDP. This implies that an increase of dengue fever cases under climate change condition leads to a lower economic growth in Malaysia. The regression coefficients of temperature moderate with dengue fever cases on GDP are -1.081 (Kuala Lumpur/Subang), -3.345 (Malacca) and -2.359 (Kuching) and are statistically significant at 10 percent and 1 percent level respectively.

The regression coefficient of sea level pressure moderated with dengue fever cases on GDP is -61.483(Kuala Lumpur/Subang) and is statistically significant at 10 percent. Besides that, in Kuantan and Kuching, humidity change moderates the relationship between dengue disease risk and economic growth (GDP). In other words, high humidity and a rise of dengue cases lead to higher economic growth. On the contrary, high humidity and a rise of dengue cases lead to a lower economic growth in Malacca and Kota Kinabalu as shown in Table IV.

Nevertheless, frequent floods and a rise of dengue fever cases lead to lower economic growth. On the other hand, rain days has no significant impact on economic growth in the selected five states.

TABLE IV: EFFECT OF DENGUE FEVER ON ECONOMIC GROWTH UNDER

\begin{tabular}{|c|c|c|c|c|c|}
\hline \multicolumn{6}{|c|}{ CLIMATE CHANGE CONDITION } \\
\hline & $\begin{array}{r}\text { Kuala Lumpur/ } \\
\text { Subang }\end{array}$ & Kuantan & Malacca & $\begin{array}{r}\text { Kota } \\
\text { Kinabalu } \\
\end{array}$ & Kuching \\
\hline$L O G(D F *$ Temperature $)$ & $\begin{array}{r}-1.081 \\
(0.062)^{*}\end{array}$ & $\begin{array}{r}0.464 \\
(0.242)\end{array}$ & $\begin{array}{r}-3.345 \\
(0.000) * * *\end{array}$ & $\begin{array}{r}-0.286 \\
(0.497)\end{array}$ & $\begin{array}{r}-2.359 \\
(0.000)^{* * * *}\end{array}$ \\
\hline $\begin{array}{l}\text { LOG }(D F * \text { Sea Level } \\
\text { Pressure }\end{array}$ & $\begin{array}{l}-61.483 \\
(0.090)^{*}\end{array}$ & NIL & $\begin{array}{r}15.690 \\
(0.692)\end{array}$ & NIL & $\begin{array}{r}22.520 \\
(0.380)\end{array}$ \\
\hline LOG(DF*Humidity) & $\begin{array}{r}0.323 \\
(0.128)\end{array}$ & $\begin{array}{r}0.528 \\
(0.069)^{*}\end{array}$ & $\begin{array}{r}-1.749 \\
(0.000)^{* * * *}\end{array}$ & $\begin{array}{r}-0.486 \\
(0.035) * *\end{array}$ & $\begin{array}{r}0.611 \\
(0.015)^{* * *}\end{array}$ \\
\hline LOG(DF*Rain Days) & $\begin{array}{r}-0.042 \\
(0.162)\end{array}$ & $\begin{array}{r}0.006 \\
(0.881)\end{array}$ & $\begin{array}{r}1.46 \mathrm{E}-07 \\
(0.397)\end{array}$ & $\begin{array}{r}-0.001 \\
(0.934)\end{array}$ & $\begin{array}{r}0.015 \\
(0.549)\end{array}$ \\
\hline$L O G(D F)$ & & & $\begin{array}{c}25.924 \\
(0.0167) * *\end{array}$ & & \\
\hline$D F * F L O O D S$ & & & $\begin{array}{l}-5.15 \mathrm{E}-06 \\
(0.004)^{* * * *}\end{array}$ & & \\
\hline $\begin{array}{l}D F^{*} E X T R E M E \_E V E N T \\
S\end{array}$ & & & $\begin{array}{l}3.16 \mathrm{E}-06 \\
(0.345)\end{array}$ & & \\
\hline Constant & & & $\begin{array}{c}176.885 \\
(0.0168)^{* *}\end{array}$ & & \\
\hline R-Squared & & & 0.740632 & & \\
\hline F-Statistic & & & 8.430608 & & \\
\hline Observation & & & 84 & & \\
\hline
\end{tabular}

\section{CONCLUSION}

Past studies reveal that health and macroeconomics are strongly correlated. One country's economic growth are determined by good health in the nation, since higher level of labor productivity, investment and education accelerate economic wellbeing. A reduction of the average income per capital was estimated when the variable of dengue disease in Malaysia was included into the economic growth model. This study is the first to contribute an analysis of the impact of dengue disease on Malaysia economic growth. As expected, the result reveals that the number of dengue cases shows a negative linear economic effect on Malaysia's economic growth, under the hazard of climate change condition.

Recent climate changes play a significant role on the dengue incidence rate in Malaysia. Precipitation changes of the study areas are significantly related to the dengue incidence rates. Temperature, sea level, humidity and rain fall are significant predictors. This finding may initiate Malaysian government to search a viable solution for climate change adaptation policies. However, climate changes are just one of the associated factors of dengue incidence rates. For future studies, population and socioeconomic factors such as education, income, household waste management and domestic water uses can be considered as predictors.

The expected number of dengue cases obtained from the forecast model can be used to model the economic growth. Subsequently prevention and recovery policies can be planned based on the dengue outbreak and the extent of inflicted economic problem.

\section{CONFLICT OF INTEREST}

The authors declare no conflict of interest.

\section{AUTHOR CONTRIBUTIONS}

Chuie-Hong Tan and See-Nie Lee conducted the research, analyzed the data and wrote the paper; Sin-Ban Ho improved and edited the paper; all authors had approved the final version.

\section{REFERENCES}

[1] S. A. Gagnon, A. B. G. Bush, and K. E. Smoyer-Tomic, "Dengue epidemics and El Nino Souther Oscillation," Clim. Res., vol. 19, pp. 35-43, 2001.

[2] Y. L. Hii, "Climate and dengue fever: Early warning based on temperature and rainfall," Umeå University Medical Dissertations New Series No 1554, Umeå, Sweden, 2013.

[3] E. A. Mordecai, J. M. Cohen, M. V. Evans, P. Gudapati, L. R. Johnson, C. A. Lippi, K. Miazgowicz, C. C. Murdock, J. R. Rohr, S. J. Ryan, V. Savage, M. S. Shocket, A. S. Ibarra, M. B. Thomas, and D. P. Weikel, "Detecting the impact of temperature on transmission of Zika, dengue, and chikungunya using mechanistic models," PLoS Negl. Trop. Dis., vol. 11, no. 4, article e0005568, 2017.

[4] Y. L. Cheong, K. Burkart, P. J. Leitão, and T. Lakes, "Assessing weather effects on dengue disease in Malaysia," International Journal Environment Res. Public Health, vol. 10, no. 12, pp. 6319-6334, 2013.

[5] N. C. Dom, A. A. Hassan, Z. A. Latif, and R. Ismail, "Generating temporal model using climate variables for the prediction of dengue cases in Subang Jaya, Malaysia," Asian Pacific J. Trop. Dis., vol. 3, no. 5, 352-361, 2013.

[6] O. J. Brady, M. A. Johansson, C. A. Guerra, S. Bhatt, N. Golding, D. M Pigott, H. Delatte, M. G. Grech, P. T Leisnham, R. Maciel-de-Freitas, L. M. Styer, D. L. Smith, T. W. Scott, P. W. Gething, and S. I. Hay, "Modelling adult Aedes aegypti and Aedes albopictus survival at different temperatures in laboratory and field settings," Parasites \& Vectors, vol. 6, no. 1, article 351, 2013. 
[7] N. E. A. Murray, M. B. Quam, and A. Wilder-Smith, "Epidemiology of dengue: Past, present and future prospects," Clin. Epidemiol, vol. 5, pp. 299-309, 2013.

[8] National Crisis Preparedness and Response Centre (CPRC), Ministry of Health Malaysia (MOH). [Online]. Available: https://idengue.mysa.gov.my/ide_v3/pdf/statistik.pdf\#page $=3 \mathrm{C}$

[9] D. E. Bloom, D. Canning, and J. Sevilla, "The effect of health on economic growth: A production function approach," World Development, vol. 32, no. 1, pp. 1-13, 2004.

[10] R. Barro, and X. Sala-I-Martin, Economic Growth, New York: McGraw-Hill, 1995.

[11] A. Bhargava, D. Jamison, L. Lau, and C. Murray, "Modeling the effects of health on economic growth," J. Health Economics, vol. 20, no. 3, pp. 423-440, 2001

[12] M. Alsan, D.E. Bloom, and D. Canning, "The effect of population health on foreign direct investment inflows to low- and middle-income countries," World Development, vol. 34, no. 4, pp. 613-630, 2006.

[13] P. Garg, J. Nagpal, P. Khairnar, and S. L. Seneviratne, "Economic burden of dengue infections in India," Trans. R. Soc. Trop. Med. Hyg., vol. 102 , no. 6, pp. 570-577, 2008.

[14] B. Armien, J. A. Suaya, E. Q. Quiroz, B. K. Sah, V. Bayard, L. Marchena, C. Campos, and D. S. Shepard, "Clinical characterists and national economic cost of the 2005 dengue epidemic in Panama," Am. $J$. Trop. Med. Hyg., vol. 73, no. 3, pp. 264-371, 2008.

[15] E. C. Holmes, P. H. Tio, D. Perera, J. Muhi, and J. Cardosa, "Importation and co-circulation of multiple serotypes of dengue virus in Sarawak, Malaysia," Virus Res., vol. 143, pp. 1-5, 2009.

[16] S. Poovaneswari, "Dengue situation in Malaysia," The Malaysian Journal of Pathology, vol. 15, no, 1, pp. 3-7, 1993.

[17] P. Gautret, P. Schlagenhauf, J. Gaudart, F. Castelli, P. Brouqui, F. von Sonnenburg, L. Loutan, and P. Parola, "Multicenter EuroTravNet/GeoSentinel study of travel-related infectious diseases in Europe," Emerging Infectious Diseases, vol. 15, pp. 1783-1790, 2009.

[18] S. Thammapalo, V. Chongsuwiwatwong, D. McNeil, and A. Geater, "The climatic factors influencing the occurrence of dengue hemorrhagic fever in Thailand," Southeast Asian J. Trop. Med. Public Health, vol. 36, pp. 191-196, 2005.

[19] B. Cazelles, M. Chavez, A. J. McMichael, and S. Hales, "Non-stationary influence of El Nino on the synchronous dengue epidemics in Thailand," PLOS Med., vol. 2, pp. 313-318, 2005.

[20] H. M. Yang, M. L. G. Macoris, K. C. Galvani, M. T. M. Andrighetti, and D. M. V. Wanderley, "Assessing the effects of temperature on the population of Aedes aegypti, the vector of dengue," Epidemiology and Infection, vol. 137, pp. 1188-1202, 2009.

[21] M. R. Amin, S. M. Tareq, S. H. Rahman, and M. R. Uddin, "Effects of temperature, rainfall and relative humidity on Visceral Leishmaniasis prevalence at two highly affected Upazilas in Bangladesh," Life Science Journal, vol. 10, no. 4, pp. 1440- 1446, 2013.

[22] K. M. Gabriel and W. R. Endlicher, "Urban and rural mortality rates during heat waves in Berlin and Brandenburg, Germany," Environ. Pollut., vol. 159, pp. 2044-2050, 2011.

[23] J. Wardekker, A. Jong, L. Bree, W. Turkenburg, and J. Sluijs, "Health risks of climate change: An assessment of uncertainties and its implications for adaptation policies," Environmental Health, vol. 11, article 67, 2012.

[24] S. K. Dickin, C. J. Schuster-Wallace, and S. J. Elliott, "Developing a vulnerability mapping methodology: Applying the water-associated disease index to dengue in Malaysia," PLOS Med., vol. 8, no. 5, pp. $1-11,2013$

[25] J. Fan, W. Wei, Z. Bai, C. Fan, S. Li, O. Liu, and K. Yang, "A systematic review and meta-analysis of dengue risk with temperature change," Int. J. Environ. Res. Public Health, vol. 12, no. 1, pp. 1-15, 2015.

[26] J. E. Pessanha, W. T. Caiaffa, and M. C. Almeida, "Diffusion pattern and hotspot detection of dengue in Belo Horizonte, Minas Gerais, Brazil," Journal of Tropical Medicine, vol. 2012, article 760951, 2012.

[27] P. Barbazan, S. Yoksan, and J.-P. Gonzalez, "Dengue hemorrhagic fever epidemiology in Thailand: description and forecasting of epidemics," Microbes Infect., vol. 4, no. 7, pp. 699-705, 2002.

[28] G. A. Abdullah, A. A. M. Mohammad, and M. A. Abdullah, "Geographical distribution and spatio-temporal patterns of dengue cases in Jeddah Governorate from 2006-2008," Trans. R. Soc. Trop. Med. Hyg., vol. 107, pp. 23-29, 2012.

[29] O. V. Sophie, H. B. Birgit, and K. Nardlada, "Multi level analyses of spatial and temporal determinants for dengue infection," Int. J. Health Geogr., vol. 5, pp. 1-16, 2006.

[30] R. G. M. Saifur, D. Hamady, and A. Hassan, "Changing domesticity of Aedes aegypti in northern Peninsular Malaysia: Reproductive consequences and potential epidemiology implications," PLoS One, vol. 7, article e30919, 2012.

[31] M. K. Hassan, and K. Lalit, "Identifying and visualizing spatial patterns and hot spots of clinically-confirmed dengue fever cases and female Aedes aegypti mosquitoes in Jeddah, Saudi Arabia," Dengue Bull., vol. 35, pp. $15-34,2011$.

[32] A. Guzman, and R. E. Isturiz, "Update on the global spread of dengue," Int. J. Antimicrob. Agents, vol. 36, pp. S40-S42, 2010.

[33] E. E. Ooi, K. T. Goh, and D. J. Gubler, "Dengue prevention and 35 years of vector control in Singapore," Emerg. Infect. Dis., vol. 12, pp. 887-893, 2006.

[34] D. S. Shepard, E. A. Undurraga, R. S. Lees, Y. A. Halasa, and L. Lum, "Use of multiple data sources to estimate the economic cost of dengue illness in Malaysia," Am. J. Trop. Med. Hyg., vol. 87, pp. 796-805, 2012.

[35] S. Kongsin, S. Jiamton, J. Suaya, S. Vasanawathana, P. Sirisuvan, and D. Shepard, "Cost of dengue in Thailand," Dengue Bull., vol. 34: pp. $77-88,2010$

[36] H. L. Lee, S. S. Vasan, L. Birgelen, T. M. Murtola, H.-F. Gong, R. W. Field, D. V. Mavalankar, N. W. Ahmad, L. S. Hakim, S. Murad, N. C. Wan, L. C. Lum, J. A. Suaya, and D. S. Shepard, "Immediate cost of dengue to Malaysia and Thailand: An estimate," Dengue Bull., vol. 34: pp. 65-76, 2010.

[37] World Travel \& Tourism Council (WTTC). The Economic Impact of Travel \& Tourism 2013. [Online]. Available: http://www.wttc.org/site_media/uploads/downloads/malaysia2013_2. pdf

[38] PCC-AR5-WG1 Climate Change, The Physical Science Basis Working Group 1 (WG1), Contribution to the Intergovernmental Panel on Climate Change (IPCC) 5th Assessment Report (AR5). Cambridge, U.K.: Cambridge University Press, 2013.

[39] N. Nakicenovic, J. Alcamo, A. Grubler, K. Riahi, R. A. Roehrl, H. H Rogner, and N. Victor, Special Report on Emissions Scenarios (SRES): A Special Report of Working Group III of the Intergovernmental Panel on Climate Change, Cambridge, U.K.: Cambridge University Press, 2000.

[40] NRE (Natural Resources and Environment), Malaysia Biennial Update Report to the UNFCC, Putrajaya, Malaysia: Ministry of Natural Resources and Environment Malaysia, 2015.

[41] M. K. Sammathuria and L. K. Ling, "Regional climate observation and simulation of extreme temperature and precipitation trends," 14th International Rainwater Catchment Systems Conference, PWTC, Kuala Lumpur, Malaysia, 3-6 August, 2009.

[42] Tutiempo Network, Weather in Malaysia - 15 days (tutiempo.net) [Online]. Available: https://en.tutiempo.net/malaysia.html

[43] Malaysian Meteorological Department, Climate Change Scenarios for Malaysia 2001-2099, Kuala Lumpur, Malaysia: Malaysia Meteorological Department, 2009.

[44] M. Khor. (19 January 2015). Lessons from the great flood. The Star [Online]. Available: https://www.thestar.com.my/opinion/columnists/global-trends/2015/0 1/19/lessons-from-the-great-floods

[45] Reuters. (5 November 2017). Flash floods kill five in Malaysia, army deploys to rescue thousands of displaced. Reuters. [Online]. Available https://www.reuters.com/article/us-malaysia-floods/flash-floods-kill-fi ve-in-malaysia-army-deploys-to-rescue-thousands-ofdisplacedidUSK BN1D50TL

[46] The Straits Times. (5 January 2018). Two Dead, Nearly 12,000 Evacuated in Malaysia floods. The Straits Times. [Online]. Available: https://www.straitstimes.com/asia/se-asia/two-dead-nearly-12000-eva cuated-in-malaysia-flfloods

[47] J. L. Loh, F. Tangang, J. Liew, D. Hein, and D. Lee, "Projected rainfall and temperature changes over Malaysia at the end of the 21 st century based on PRECIS modelling system," Asia-Pac. J. Atmos. Sci., vol. 52, no. 2, pp. 191-208, 2016.

[48] C. P. Chang, P. A. Harr, and H. J. Chen, "Synoptic disturbances over the equatorial South China Sea and western Maritime Continent during boreal winter," Mon. Weather Rev., vol. 133, pp. 489-503, 2005.

[49] A. K. Rahman, R. Abdullah, N. Balu, and F. M. Shariff, "The impact of La Nina and El Nino events on crude palm oil prices: An econometric analysis," Oil Palm Ind. Econ. J., vol. 13, no. 2, pp. 38-51, 2013.

Copyright $(2022$ by the authors. This is an open access article distributed under the Creative Commons Attribution License which permits unrestricted use, distribution, and reproduction in any medium, provided the original work is properly cited ( $\underline{\text { C BY 4.0) }}$. 


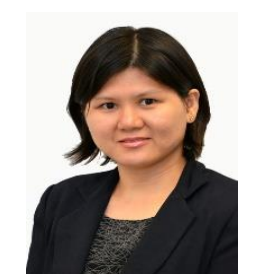

Chuie-Hong Tan received a B.A. hons. (math) and an M.App. statistics from University of Malaya, Kuala Lumpur, Malaysia in 1999 and 2001, and the $\mathrm{PhD}$ degree in management from the Multimedia University, Cyberjaya, Malaysia in 2009. She is a senior lecturer in the Faculty of Management, Multimedia University, Cyberjaya, Malaysia. Her primary research interest includes environmental sustainability, climate change, social science, focusing on statistical and quantitative analysis.

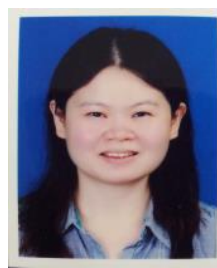

See-Nie Lee received the $\mathrm{PhD}$ degree in finance from the Universiti Putra Malaysia, Selangor, Malaysia in 2016. Her PhD thesis investigates the variety types of indicators driven the volatility contagion. It explores how financial sectors, non-financial sectors, macro-financial variables and country risk affect volatility contagion in selected six Asia countries. She is a research officer in the Faculty of Management,
Multimedia University, Cyberjaya, Malaysia. Her research passion includes economic growth, finance, environmental sustainability, statistical and quantitative analysis.

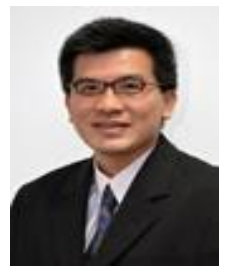

Sin-Ban Ho received a B.Sc. and an M.Sc. in computer science from the University of Science Malaysia, Penang, Malaysia in 1998 and 1999, and the Ph.D. degree in information technology from the Multimedia University, Cyberjaya, Malaysia in 2008. He is a senior lecturer in the Faculty of Computing and Informatics, Multimedia University, Cyberjaya, Malaysia. His research interests include environmental systems, climate change, machine learning, health informatics, patterns analysis, and empirical research approach. He is a senior member of the IEEE and IEEE Computer Society. 